\title{
Peertechz
}

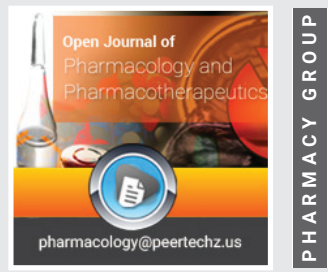

Research Article

\section{Controlled release of 5-Fluorouracil} by a novel L-Lysine based polyesterurethane material synthesized from Epoxide and $\mathrm{CO}_{2}$ via a novel dicopper salen catalyst

\section{Arunangshu Kundu ${ }^{1,2}$, Gobinda Chandra $\mathrm{De}^{2 \star}$ and Sushobhan Ghosh ${ }^{1 *}$}

${ }^{1}$ Associate Professor, Department of Chemistry, Alipurduar College, Westbengal, India

${ }^{2}$ Department of Chemistry, Coochbehar Panchanan Barma University, Westbengal, India
Received: 22 December, 2021

Accepted: 12 January, 2022

Published: 13 January, 2022

*Corresponding authors: Dr. Sushobhan Ghosh, Associate Professor, Department of Chemistry, Alipurduar College, Westbengal, India, Tel: 8101906711; E-mail: sushobhan.iisc@gmail.com

Associate Professor, Dr. Gobinda Chandra De, Department of Chemistry, Coochbehar Panchanan Barma University, Westbengal, India,

E-mail: degobinda@yahoo.com

ORCID: https://orcid.org/0000-0002-8440-7494

https://orcid.org/0000-0002-2765-4552

Keywords: Polyesterurethane; Cyclic carbonate; Controlled Release; 5-Fluorouracil

Copyright License: (c) 2022 Kundu A, et al. This is an open-access article distributed under the terms of the Creative Commons Attribution License, which permits unrestricted use, distribution, and r eproduction in any medium, provided the original author and source are credited.

https://www.peertechzpublications.com

Check for updates

\begin{abstract}
Controlled release of anticancer drug 5-Fluorouracil by several delivery systems are known including porous polymeric materials. Herein we report a novel L-lysine based porous polyesterurethane material 1 which acts as a controlled release vehicle for 5-Fluorouracil. Polyesterurethane material 1 was synthesized from a green isocyanate and phosgene free synthetic route involving conversion of epoxide 2-(phenoxymethyl)oxirane and $\mathrm{CO}_{2}$ to cyclic carbonate 2 followed by ring opening with an amino acid L-Lysine to a bishydroxy compound 3 under green aqueous reaction condition. The bishydroxy compound 3 was subsequently reacted with 0.66 equivalent of trimesyl chloride in presence of triethyl amine to get the polyesterurethane material 1. The polyesterurethane material 1 was characterized via NMR, IR and MALDI analysis. From the SEM image of the polyesterurethane 1 and 5-Fluorouracil encapsulated polyesterurethane 1 it is evident that material 1 remain with porous topology which is filled by 5 -Fluorouracil that is further evidenced by EDX spectroscopy with the presence of Fluorine. The controlled release of 5-Fluorouracil from the drug encapsulated 1 was monitored via UV visible spectroscopy at $\mathrm{pH} 7.4$.
\end{abstract}

Cancer is a disease in which some of the body's cells grow uncontrollably and spread to other parts of the body. Cancer can start almost anywhere in the human body, which is made up of trillions of cells. Normally, human cells grow and multiply to form new cells as the body needs them. When cells grow old or become damaged, they die, and new cells take their place. Cancer is the second most common disease which responsible for deaths all over the world. Therefore, treatments of cancer offer a huge challenge. Many medications are available for cancer treatment [1-6], among this 5-flurouracil plays a major role by exerting its anticancer effects through inhibition of thymidylate synthase (TS) and incorporation of its metabolites into RNA and DNA. Although 5-flurouracil is an established anticancer drug for colon cancer, esophageal cancer, stomach cancer, pancreatic cancer, breast cancer, and cervical cancer [7-10]. but in order to increase its efficacy several nanodrug delivery system has been explored for transporting anti-cancer drugs to colorectal cancer cells, while reducing undesired drug distribution in healthy tissues. $\mathrm{CO}_{2}$ can be converted different value added materials $[11,12]$ and among which conversion of epoxides to cyclic carbonates are well known [13-15]. Global warming is considered to be a serious challenge in the perspective of the earth's habitable climate conditions for which increasing rate of $\mathrm{CO}_{2}$ emission is one of the main causes. Conversion of $\mathrm{CO}_{2}$ to value added materials happened to be the main way out for reducing the 
rate of $\mathrm{CO}_{2}$ emission. Many reports of conversion of $\mathrm{CO}_{2}$ to value added materials are known [16] among which conversion of epoxides to cyclic carbonates are well known [16-21]. Cyclic carbonates can be utilized for different purposes including the production of polyurethane and polyesterurethane materials [16-21]. Polyesterurethane materials from biobased substrates are important for their versatile applications as biodegradable materials in bone tissue engineering as well as hydrogels for drug delivery and in biomedicine [22-25]. These biobased polyesterurethane materials are widely synthesized from respective diols and diiosocyanates [26-28]. Diisocyanate precursors are prepared from the diamines in presence of phosgene [29]. Organic isocyanates are very toxic for the human health which was proved during Bhopal gas disaster and phosgene is also considered to be highly toxic as $50 \mathrm{ppm}$ exposure may cause lethal reaction in humans. In order to avoid the involvement of diisocyanates and phosgene for the production of polyesterurethane materials an alternative procedure has been discovered where ring opening of a cycliccarbonate in presence of diamines give the respective bishydroxy compound which then undergo copolymerization with the acid chlorides to generate the polyesterurethane materials [30,31]. Here we have first successfully synthesized the ringopened bishydroxy compound 3 by reacting the monocyclic carbonate 4-(phenoxymethyl)-1, 3-dioxolan-2-one (2) with the amino acid L-Lysine in presence of water at $120^{\circ} \mathrm{C}$ (Scheme 1). The ring opened diol 3 was converted into polyesterurethane

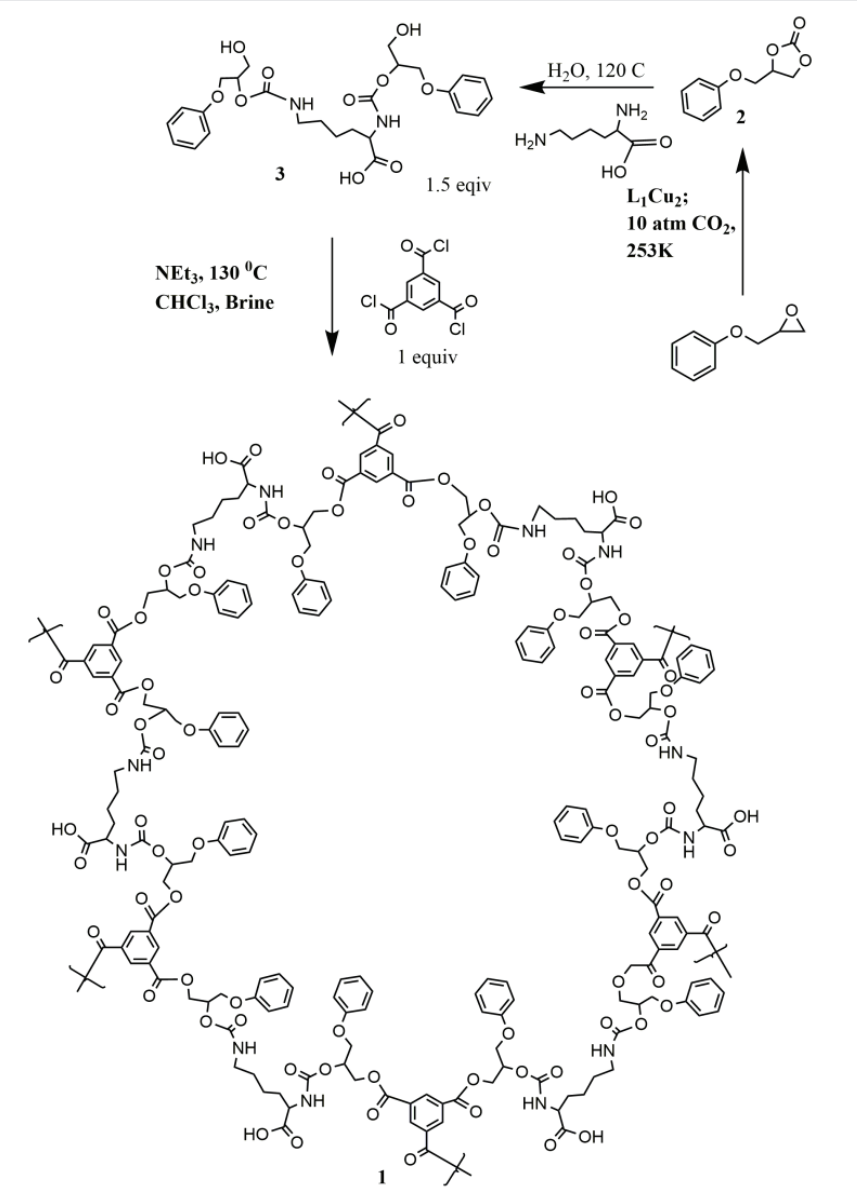

Scheme 1: Synthesis of the polyesterurethane material 1 from L-lysine and cyclic carbonate 2 . material 1 by reacting it with trimesyl chloride in 3: 2 rations in presence of triethyl amine as shown in Scheme 1.

Although there are reports of several [32], polyurathene based material used as control drug release vehicle but there is no report of polyesterurethane material generated from amino acid which is considered to be a very promising candidate for the development of drug release vehicles as it has been done in our present work. Hence the crosslink polymeric network which has been synthesized from amino acid L-lysine and working as a very good drug vehicle for anti-cancer drug 5-fluorouracil can be considered as a novel route for the delivery of drug material based on polymeric networks designed from bioactive materials.

The synthesis of cyclic carbonate 2 was achieved by conversion of epoxide 2-(phenoxymethyl)oxirane in presence of $\mathrm{CO}_{2}$ using an efficient novel supramolecular rectangular bis salen dicopper complex heterogeneous catalyst $\mathrm{L}_{1} \mathrm{Cu}_{2}$. Salen based catalysts with different metallic systems have been widely used for the catalysis of the cyclic carbonates but the copper based salens have been rarely used for this purpose [33]. As copper salts are commercially readily available and cheap hence the use of copper based catalysts in the cyclic carbonate synthesis would be interesting. The synthesis of the novel copper based catalyst $\mathrm{L}_{1} \mathrm{Cu}_{2}$ was performed according to the synthetic Scheme 2 with the final catalyst being characterized clearly by MALDI as well as elemental analysis. The MALDI spectra of the copper complex $\mathrm{L}_{1} \mathrm{Cu}_{2}$ shows the molecular ion peak as $[\mathrm{M}]+$ at 1200.0792 with respect to the expected mass at 1200.1753 (Figure $\mathrm{S}_{4}$ ). The free salen ligand $\mathrm{L}_{1}$ was also detected in the MALDI spectra at 1076.1738. The reaction of the salicylaldehyde proligand $\mathrm{L}$ with orthophenylene diamine in 1:1 ratio in presence of two equivalent of copper acetate generates the catalyst $\mathrm{L}_{1} \mathrm{Cu}_{2}$. The salicylaldehyde proligand $\mathrm{L}$ was synthesized by the reaction of protected 5-bromo-2hydroxybenzaldehyde with 1,8 diethynyl anthracene in 2:1 ratio as shown in Scheme 2.

The salicylaldehyde proligand L was fully characterized by NMR and ESI MS studies. In the proton NMR spectra the peak at $10.13 \mathrm{ppm}$ corresponds to the aldehyde proton whereas in ${ }^{13} \mathrm{C}$ NMR spectra the carbonyl carbon appears at $190.93 \mathrm{ppm}$ (Figure S1 and Figure S2). The ESI MS in negative mode gives the $[\mathrm{M}-\mathrm{H}]-$ peak at 465.0635 as compared to the expected peak at 465.1127. (Figure S3).

Cyclic carbonate 2 was synthesized by reaction of the epoxide 2-(phenoxymethyl)oxirane with $\mathrm{CO}_{2}$ at 10 atmospheric pressure and 80 degrees centigrade in a high pressure steel reactor in 95\% yield (Scheme1). The reaction was carried out without any solvent and the catalyst $\mathrm{L}_{1} \mathrm{Cu}_{2}$ was used in 0.062 mol\% along with cocatalyst tetrabutyl ammonium bromide $0.23 \mathrm{~mol} \%$ for the purpose with turnover number more than 1200. The catalytic efficiency of the novel copper salen complex is quite promising as compared to the previously reported salen based catalysts for the conversion of epoxides to cyclic carbonates [34] with the aluminium disalen complex showing the highest turnover number 1027 with $1 \mathrm{~mol} \%$ of catalyst and cocatayst loading [25]. It has been found previously that the

Citation: Kundu A, De GC, Ghosh S (2022) Controlled release of 5-Fluorouracil by a novel L-Lysine based polyesterurethane material synthesized from Epoxide and $\mathrm{CO}_{2}$ via a novel dicopper salen catalyst. Open J Pharmacol Pharmacother 7(1): 001-006. DOI: https://dx.doi.org/10.17352/ojpp.000019 


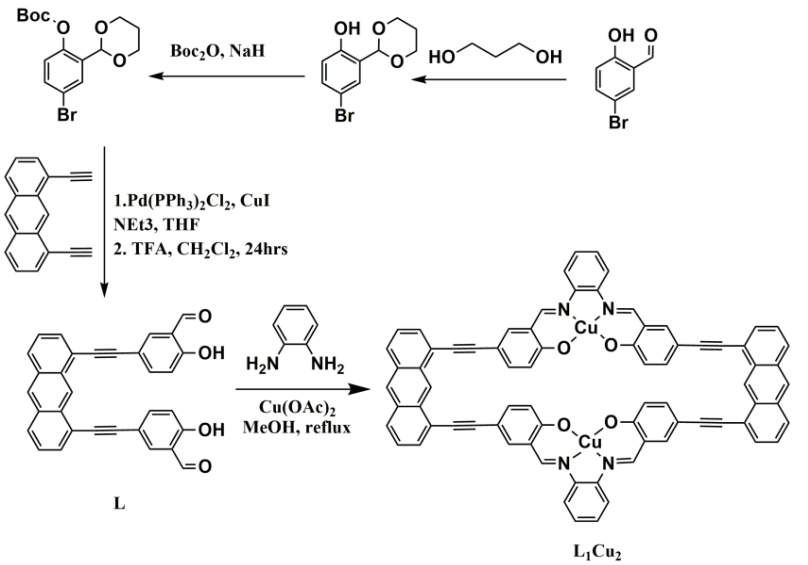

Scheme 2: Synthesis of the copper salen catalyst $\mathrm{L}_{1} \mathrm{Cu}_{2}$ for the synthesis of cyclic carbonate 3 from $\mathrm{CO}_{2}$ and epoxide 2-(phenoxymethyl)oxirane.

dinuclear salen complexes [35] have better efficiency than the mononuclear salen complexes in the synthesis of cyclic carbonate from epoxide and $\mathrm{CO}_{2}$. The mechanistic detail given by North et.al [36] shows that the dinuclear salen complexes acts simultaneously by binding both the epoxide and $\mathrm{CO}_{2}$ and bringing them in close proximity for the conversion of cyclic carbonates. Based on this we try to designed our dinuclear salen catalyst where both the metal active sites can simultaneously bind the epoxide and $\mathrm{CO}_{2}$ and increase the possibility of formation of cyclic carbonate by many fold which is reflected in our case in higher turn over number in formation of cyclic carbonates as compared to the mononuclear salen complexes or conventional catalyst such as Li salt which can provide only one metal active site per catalyst molecules. The formation of the cyclic carbonate 2 was initially indicated by the IR spectroscopy with the characteristic carbonyl stretching frequency corresponding to the cyclic carbonate appearing at $1793 \mathrm{~cm}^{-1}$ (Figure S6). The ${ }^{13} \mathrm{C}$ NMR shows the carbonyl carbon peak at 155 ppm corresponding to the cyclic carbonate 2 whereas the proton NMR spectra shows the complete disappearance of the peaks between $3.2-2.6 \mathrm{ppm}$ marking the conversion of the epoxide to the corresponding dicyclic carbonate 2 (Figure S7). Very few reports are there for the ring opening of the cyclic carbonates by the bioactive amino acid in presence of water [37]. For the best of our knowledge this is the first example of the ring opening of a monocyclic carbonate by a diamino acid L-Lysine under green aqueous reaction condition. The product 3 was fully characterized via NMR as well as mass spectrometry. Novel porous polyesterurethane polymer 1 was synthesized by reacting ring opened diol 3 and trimesyl chloride in 3: 2 ratio at $130{ }^{\circ} \mathrm{C}$ in presence of triethyl amine. Compound 1 was isolated from the reaction mixture by successive washing with chloroform and brine solution. Compound 1 was initially characterized by proton NMR where the single peak at $8.6 \mathrm{ppm}$ corresponds to the trimesyl protons and also comparing the proton NMR of the ring opened diol 3 with that of polymer 1 it is evident that compound 1 possesses a symmetrical structure. IR spectra of the ( Figure S18) polymer compound 1 shows the peak at $1689,1222,2852$ and $2915 \mathrm{~cm}^{-1}$ which is comparable to standard polyesterurethane material $[21,38]$. The MALDI mass of compound 1 shows a typical polymeric nature with successive difference between two peaks corresponding to the successive expulsion of $\mathrm{CH}_{2}$ or $\mathrm{NH}_{2}$ groups respectively from the polymeric backbone (Figure S19). The TGA data of the polymer 1 shows initial mass loss of $8.47 \%$ at $70{ }^{\circ} \mathrm{C}$ corresponding to the expulsion of solvent from the material (Figure S20). Although there are several porous organic polymers [39-42] and polyurethane [43-46] based polymers have been reported for controlled drug delivery till date there are no report based on the amino acid containing polyesterurethane material Figure 1.

SEM image of 1 as shown in figure1 clearly indicates the formation of the porous polymeric network as proposed in Scheme1. The pour size distribution was performed from the respective SEM images where it shows the average pour size distribution for the crosslink polymeric network between 0.1 - $0.6 \mu \mathrm{m}$ as shown in Figure S23. 5- Fluorouracil is a well known drug for colon cancer, esophageal cancer, stomach cancer, pancreatic cancer, breast cancer, and cervical cancer. In order to improve the therapeutic effect of this drug the controlled release of 5 fluorouracil is very important. To achieve the controlled release of 5 fluorouracil first the successful encapsulation inside the porous network of the polymer 1 was attempted by stirring the polymer 1 in the respective aqueous solutions of the 5- fluorouracil for approximately 5 hours at room temperature. The encapsulation was initially monitored via SEM imaging studies. The EDX spectra of the SEM image conclusively proves the dispersion of the drug molecules inside the porous polymeric network of 1 (Figure S22 and S24 ) by the appearance of the fluorine in the drug encapsulated SEM image of the polymer 1 whereas the EDX spectra of the pure polymer do not show any peak corresponding to fluorine. The IR data of the encapsulated polymer 1 (Figure S21) shows the retention of the polyesterurethane material after encapsulation.

The NMR data recorded in DMSO- $\mathrm{d}_{6}$ of the 5 -flurouracil encapsulated polymeric network clearly reveals the encapsulation of 5 -flurouracil in the polymeric network in both proton and C13 NMR displaying slight upfield shift of the trimesyl proton in the proton NMR of the 5-fluorouarcil encapsulated polymer with resprct to polymer 1 as shown in S16 and S17. We propose that the upfield shift of the trimesyl proton could be due to the interaction between polymer 1 and encapsulated drug 5-fluorouracil. The proton NMR spectra of encapsulated 5-fluorouracil polymeric network also show the encapsulation of approximately 3 5-flurouracil unit per polymeric network unit as stated from the proton NMR integration ratios in Figure S15.

The controlled release of the 5-fluorouracil drug was monitored via UV vis spectroscopic studies using the drug encapsulated polymer 1 in phosphate buffer at $\mathrm{pH} 7.4$ and taking out the aliquots solutions for UV measurement at certain time intervals. As represented in Figure 2 the drug release kinetics showed $80 \%$ of the drug being released within 4 hours.

\section{Conclusion}

We have synthesized the porous polyesterurethane polymeric material 1 via ring opening of a cyclic carbonate by aminoacid L-Lysine. Polymer 1 was characterized by IR, NMR as well as MALDI analysis whereas the porous texture of the 
a)

b)
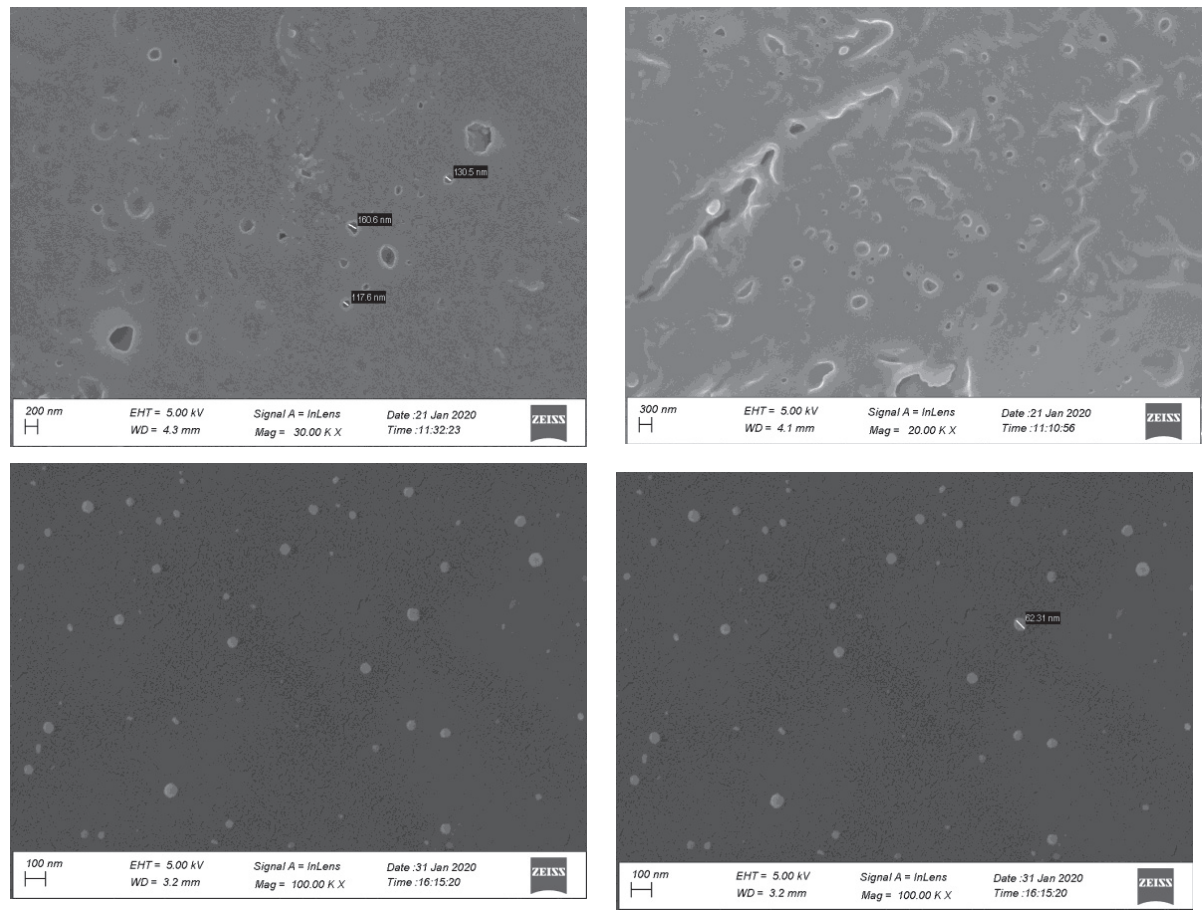

Figure 1: SEM image of the polyesterurethane polymer 1 (a) and polyesterurethane polymer 1 after encapsulation of the 5 fluorouracil drug (b).

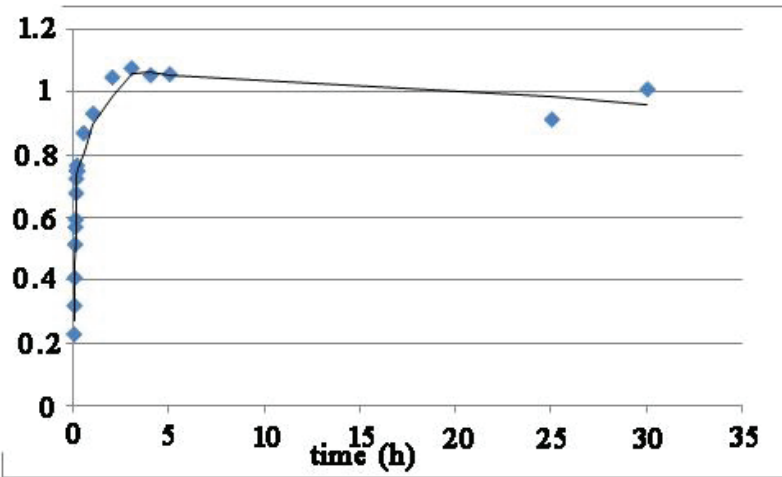

Figure 2: Controlled release of 5-Fluorouracil from the 5 Fluorouracil -polyesterurethane 1 composite. (Y-axis represent the concentration of the 5 Fluorouracil in the buffer solution at pH 7.4 in terms of optical absorption whereas $X$-axis represents the time interval).

material was observed in SEM. The cyclic carbonate synthesis was achieved by a novel supramolecular dicopper salen catalyst from the respective epoxide and carbon dioxide in high yield under heterogeneous reaction conditions. The ring opening of the cyclic carbonate was performed under green aqueous conditions to obtain a novel dihydroxo compound 3. The anticancer drug 5 fluorouracil was successfully encapsulated inside the porous polymer 1 which was evident from the FESEM analysis. The drug-polymer composite showed the controlled release kinetics of the drug 5 fluorouracil under $7.4 \mathrm{pH}$. This is the first example of an amino acid based polyesterurethane material being found to have potential for a controlled delivery vehicle for 5 fluorouracil.

\section{Acknowledgment}

This work was supported by DST SERB Early Career Research
Award grant no. ECR/2015/000227. We also acknowledge Royal Society Newton International Funding for providing us alumni fund.

$$
\begin{aligned}
& \text { 'Suplementary-Figures S1-S24)! } \\
& \text { References }
\end{aligned}
$$

1. Ali I, Saleem K, Wesselinova D, Haque A (2013) CHEMISTRY Synthesis, DNA Binding, Hemolytic, and Anti-Cancer Assays of Curcumin I-Based Ligands and Their Ruthenium ( III ) Complexes. Med Chem Rese 22: 1386-1398. Link: https://bit.ly/3zOC7SB

2. Ali I, Wani WA, Haque A, Saleem K (2013) Glutamic Acid and Its Derivatives Candidates for Rational Design of Anticancer Drugs. Future Med Chem 5: 961 978. Link: https://bit.ly/3qh44PS

3. Ali I, Aboul-enein HY, Ghanem A (2005) Enantioselective Toxicity and Carcinogenesis. Current Pharmaceutical Analysis 1: 109-125. Link: https://bit.ly/3GI5a2F

4. Ali I, Lone MN, Aboul-Enein MY (2017) Imidazoles as Potential Anticancer Agents. Med Chem Comm 8: 1742-1773. Link: https://bit.ly/3qiNcbp

5. Ali I (2011) Nano Anti-Cancer Drugs: Pros and Cons and Future Perspectives Curr Cancer Drug Targets 11: 131-134. Link: https://bit.ly/33cag2H

6. Ali I, Nadeem LMA, Al-Othman Z, Al-Warthan A, Marsin Sangi M (2015) Heterocyclic Scaffolds: Centrality in Anticancer Drug Development. Curr Drug Targets 16: 711-734. Link: https://bit.ly/3nkW6Dj

7. Ali I, Rahisuddin, Saleem K, Aboul-Enein HY, Rather A (2010) Socia Aspects of Cancer Genesis Review Article. Cancer Therapy 8: 6-14. Link: https://bit.ly/3fiel2

8. Ali I, Wani WA, Khan A, Haque A, Ahmad A, et al. (2012) Synthesis and Synergistic Antifungal Activities of a Pyrazoline Based Ligand and Its Copper (II) and Nickel (II) Complexes with Conventional Antifungals. Microb Pathog 53: 66-73. Link: https://bit.ly/3Fdla4g 
9. Ali I, Wani WA, Saleem K, Wesselinova D (2013) Syntheses, DNA Binding and Anticancer Profiles of L-Glutamic Acid Ligand and Its Copper (II) and Ruthenium (III) Complexes. Med Chem 9: 11-21. Link: https://bit.ly/3Go6eCN

10. Ali I, Wania WA, Saleem K, Hsieh MF (2014) Anticancer Metallodrugs of Glutamic Acid Sulphonamides: In Silico, DNA Binding, Hemolysis and Anticancer Studies. RSC Adv 4: 29629-29641. Link: https://rsc.li/3330Q8d

11. Mondal B, Sen $P$, Rana A, Saha D, Das $P$, et al. (2019) Reduction of $\mathrm{CO}_{2}$ to $\mathrm{CO}$ by an Iron Porphyrin Catalyst in the Presence of Oxygen. ACS Catal 9: 38953899. Link: https://bit.ly/3rdshFN

12. Sau SC, Bhattacharjee R, Vardhanapu PK, Vijaykumar G, Datta A, et al. (2016) Metal-Free Reduction of CO2to Methoxyborane under Ambient Conditions through Borondiformate Formation. Angew Chemie Int Ed Engl 55: 1514715151. Link: https://bit.ly/3Gk4YRd

13. Gennen S, Grignard B, Tassaing T, Jérôme C, Detrembleur C (2017) $\mathrm{CO}_{2}$ -Sourced a-Alkylidene Cyclic Carbonates: A Step Forward in the Quest for Functional Regioregular Poly(Urethane)s and Poly(Carbonate)S. Angew. Chemie - Int Ed 56: 10394-10398.

14. Darensbourg DJ, Holtcamp MW (1996) Catalysts for the Reactions of Epoxides and Carbon Dioxide. Coord Chem Rev 153: 155-174. Link: https://bit.ly/3t|43MM

15. Lu XB, Darensbourg DJ (2012) Cobalt Catalysts for the Coupling of $\mathrm{CO}_{2}$ and Epoxides to Provide Polycarbonates and Cyclic Carbonates. Chem Soc Rev 41: 1462-1484. Link: https://rsc.li/3Gx8fwo

16. Wang Z, Zhang X, Zhang L, Tan T, Fong H (2016) Nonisocyanate Biobased Poly(Ester Urethanes) with Tunable Properties Synthesized via an Environment-Friendly Route. ACS Sustain Chem Eng 4: 2762-2770. Link: https://bit.ly/3r7fSDz

17. Fortman DJ, Brutman JP, Cramer CJ, Hillmyer MA, Dichtel WR (2015) Mechanically Activated, Catalyst-Free Polyhydroxyurethane Vitrimers. J Am Chem Soc 137: 14019-14022. Link: https://bit.ly/3Gs9pJW

18. González-García DM, Marcos-Fernández Á, Rodríguez-Lorenzo LM Jiménez-Gallegos R, Vargas-Becerril N, et al. (2018) Synthesis and in Vitro Cytocompatibility of Segmented Poly(Ester-Urethane)s and Poly(Ester-UreaUrethane)s for Bone Tissue Engineering Polymers (Basel) 10: 991. Link: https://bit.ly/3nj7y2n

19. Yuen A, Bossion A, Gómez-Bengoa E, Ruipérez F, Isik M, et al. (2016) Room Temperature Synthesis of Non-Isocyanate Polyurethanes (NIPUs) Using Highly Reactive N-Substituted 8-Membered Cyclic Carbonates. Polym Chem 7: 2105-2111. Link: https://rsc.li/3A3QTVT

20. Beniah G, Fortman DJ, Heath WH, Dichtel WR, Torkelson JM (2017) Non-Isocyanate Polyurethane Thermoplastic Elastomer: Amide-Based Chain Extender Yields Enhanced Nanophase Separation and Properties in Polyhydroxyurethane. Macromolecules 50: 4425-4434. Link: https://bit.ly/3zR7pbx

21. Matsukizono H, Endo T (2018) Reworkable Polyhydroxyurethane Films with Reversible Acetal Networks Obtained from Multifunctional Six-Membered Cyclic Carbonates. J Am Chem Soc 140: 884-887. Link: https://bit.ly/3zPBPL7

22. Lendlein A, Langer R (2002) Biodegradable, Elastic Shape-Memory Polymers for Potential Biomedical Applications. Science 296: 1673-1676. Link: https://bit.ly/3FjhGOW

23. Han XJ, Dong ZQ, Fan MM, Liu Y, Li JH, et al. (2012) PH-Induced Shape Memory Polymers. Macromol Rapid Commun 33: 1055-1060. Link: https://bit.ly/3GooOus

24. Metcalfe A, Desfaits AC, Salazkin I, Yahia L, Sokolowski WM, et al. (2003) Cold Hibernated Elastic Memory Foams for Endovascular Interventions. Biomaterials 24: 491-497.Link: https://bit.ly/3I1CrjV

25. Yakacki CM, Shandas R, Lanning C, Rech B, Gall K (2009) Polymer Networks for Cardiovascular Applications. Biomaterials 28: 2255-2263. Link: https://bit.ly/33cyUjV

26. Oulame MZ, Pion F, Allauddin S, Raju KVSN, Ducrot PH, et al. (2015) Renewable Alternating Aliphatic-Aromatic Poly(Ester-Urethane)s Prepared from Ferulic Acid and Bio-Based Diols. Eur Polym J 63: 186-193. Link: https://bit.ly/338Xv96

27. Selukar BS, Parwe SP, Mohite KK, Garnaik B (2012) Synthesis and Characterization of Linear Polylactic Acid-Based Urethanes Using Tin Modified Solid Cloisite-30B Catalyst. Adv Mater Lett 3: 161-171. Link: https://bit.ly/3KeGawq

28. Delebecq E, Pascault JP, Boutevin B, Ganachaud F (2013) On the Versatility of Urethane/Urea Bonds: Reversibility, Blocked Isocyanate, and Non-Isocyanate Polyurethane. Chem Rev 113: 80-118. Link: https://bit.ly/3r9yfHY

29. Bachmann F, Reimer J, Ruppenstein M, Thiem J (2001) Synthesis of Novel Polyurethanes and Polyureas by Polyaddition Reactions of Dianhydrohexito Configurated Diisocyanates. Macromol Chem Phys 202: 3410-3419. Link: https://bit.ly/3zMlrtS

30. Kundu A, De GC, Ghosh S (2019) Green Synthesis of Novel Polyesterurethane Materials from Epoxides and Carbon Dioxide by New Set of One-Dimensional Coordination Polymer Catalyst. ACS Omega 4: 14074-14084. Link: https://bit.ly/3HUiXgY

31. Wang Z, Zhang X, Zhang L, Tan T, Fong H (2016) Nonisocyanate Biobased Poly(Ester Urethanes) with Tunable Properties Synthesized via an Environment-Friendly Route. ACS Sustain Chem Eng 4: 2762-2770. Link: https://bit.ly/3FlaWA7

32. Uhrich KE, Cannizzaro SM, Langer RS, Shakesheff KM (2010) Chemlnform Abstract: Polymeric Systems for Controlled Drug Release. Chemlnform 31. Link: https://bit.ly/3Fe0Q30

33. Shen YM, Duan WL, Shi M (2003) Chemical Fixation of Carbon Dioxide Catalyzed by Binaphthyldiamino $\mathrm{Zn}, \mathrm{Cu}$, and Co Salen-Type Complexes. J Org Chem 68: 1559-1562. Link: https://bit.ly/3feDxw2

34. Martín C, Fiorani G, Kleij AW (2015) Recent Advances in the Catalytic Preparation of Cyclic Organic Carbonates. ACS Catal 5 : 1353-1370. Link: https://bit.ly/33sP3B

35. Clegg W, Harrington RW, North M, Pasquale R (2010) Cyclic Carbonate Synthesis Catalysed by Bimetallic Aluminium-Salen Complexes. Chem A Eur $J$ 16: 6828-6843. Link: https://bit.ly/3GkVAwx

36. North M, Pasquale R (2009) Mechanism of Cyclic Carbonate Synthesis from Epoxides and CO2. Angew Chemie Int Ed 48: 2946-2948. Link: https://bit.ly/3HVwbdb

37. Olsén P, Oschmann M, Johnston EV, Åkermark B (2018) Synthesis of Highly Functional Carbamates through Ring-Opening of Cyclic Carbonates with Unprotected a-Amino Acids in Water. Green Chem 20: 469-475.

38. Kihara N, Kushida Y, Endo T (1996) Cyclic Carbonate and L-Lysine Derivatives. J Polym Sci Part A Polym Chem 34: 2173-2179. Link: https://bit.ly/3tgdkFP

39. Mitra S, Sasmal HS, Kundu T, Kandambeth S, Illath K, et al. (2017) Targeted Drug Delivery in Covalent Organic Nanosheets (CONs) via Sequentia Postsynthetic Modification. J Am Chem Soc 139: 4513-4520. Link: https://bit.ly/3rdSggm

40. Zhang G, Li X, Liao Q, Liu Y, Xi K, et al. (2018) Water-Dispersible PEG-Curcumin/ Amine-Functionalized Covalent Organic Framework Nanocomposites as Smart Carriers for in Vivo Drug Delivery. Nat Commun 9: 1-11. Link: https://go.nature.com/3t|4QNF

41. Tibbitt MW, Dahlman JE, Langer R (2016) Emerging Frontiers in Drug Delivery. J Am Chem Soc 138: 704-717. Link: https://bit.ly/3Fe7hnu

42. Fang Q, Wang J, Gu S, Kaspar RB, Zhuang Z, et al. (2015) 3D Porous Crystalline

Citation: Kundu A, De GC, Ghosh S (2022) Controlled release of 5-Fluorouracil by a novel L-Lysine based polyesterurethane material synthesized from Epoxide and $\mathrm{CO}_{2}$ via a novel dicopper salen catalyst. Open J Pharmacol Pharmacother 7(1): 001-006. DOI: https://dx.doi.org/10.17352/ojpp.000019 
Polyimide Covalent Organic Frameworks for Drug Delivery. J Am Chem Soc 37: 8352-8355. Link: https://bit.ly/333XRhz

43. Ding M, Li J, Tan H, Fu Q (2012) Self-Assembly of Biodegradable Polyurethanes for Controlled Delivery Applications. Soft Matter 8: 5414-5428. Link: https://rsc.li/3HWLQJj

44. Basu A, Farah S, Kunduru KR, Doppalapudi S, Khan W, et al. (2016) Polyurethanes for Controlled Drug Delivery; Elsevier Ltd. Link: https://bit.ly/3HUTnbJ
45. Cherng JY, Hou TY, Shih MF, Talsma H, Hennink WE (2013) PolyurethaneBased Drug Delivery Systems. Int J Pharm 450: 145-162. Link: https://bit.ly/3zYxR36

46. Kohjiya S, Ikeda Y, Takesako S, Yamashita S (1991) Drug Release Behavior from Polyurethane Gel. React Polym 15: 165-175. Link: https://bit.ly/3zSCn2N
Discover a bigger Impact and Visibility of your article publication with

Peertechz Publications

\section{Highlights}

* Signatory publisher of ORCID

* Signatory Publisher of DORA (San Francisco Declaration on Research Assessment)

* Articles archived in worlds' renowned service providers such as Portico, CNKI, AGRIS, TDNet, Base (Bielefeld University Library), CrossRef, Scilit, J-Gate etc.

* Journals indexed in ICMJE, SHERPA/ROMEO, Google Scholar etc.

* OAI-PMH (Open Archives Initiative Protocol for Metadata Harvesting)

* Dedicated Editorial Board for every journal

* Accurate and rapid peer-review process

* Increased citations of published articles through promotions

* Reduced timeline for article publication

Submit your articles and experience a new surge in publication services

(https://www.peertechz.com/submission). 